\title{
ДУХОВНО-СИМВОЛІЧНА ПОКОЛІННА ЄДНІСТЬ: ВІЛЬГЕЛЬМ ДІЛЬТЕЙ І ХОСЕ ОРТЕГА-І-ГАССЕТ
}

У контексті аналізу особливостей конструювання поколінного простору науковцями романтично-гуманітарного підходу виокремлено ідеї пошуку сутності духовно-символічної поколінної єдності і пов'язування історичних подій з конструюванням поколінної реальності. Обгрунтовано необхідність визначення атрибутивних ознак поколінності в працях Вільгельма Дільтея і Хосе Ортеги-і-Гассета як теоретичного підгрунтя пізнання феномену поколінності. Здійснено порівняльний аналіз різниці генеалогічних та філософсько-історичних позицій науковців у трактуванні поняття покоління. Виявлено загальні ознаки, за якими Дільтей і Ортега об'єднували покоління в групу осіб (єдина “зона” дат народження, історичний досвід у роки становлення, соціальні відносини, спільні культурні тенденції, національні й етнічні форми, мовні особливості, територіальне розташування). Представлено показники поколінної єдності через константи духовної сутності, іiі ознаки, функціональність, автентичність та ін. Проаналізовано природничі і духовні поколінні антитези в поєднанні життя і досвіду, минулого і сучасного, змінного і незмінного. Визначено, що періоди функціо-нування поколінь мають обмежений термін за генеалогічним принципом, а соціальні еволюційні курси духовних рухів пов'язані з поколінним хронологічним виміром психічного часу, формою суспільного життя і набутим досвідом (Дільтей), при цьому період домінування покоління сучасників над їхніми пращурами і нащадками обмежується лише п'ятнадцятирічним часовим відрізком (Ортега). У результаті аналізу змінних і незмінних констант поколінного феномену з'ясовано, що Дільтей пов'язує особливості еволюційного історичного шляху конст-руювання духовного світу та історичні знання поколінь, а Ортега, навпаки, наголошує на незмінності субстанції духовної суті - “душі і тіла” як психофізіологічного суб’єкта, i ритму історичних змін у світі переплетених життів, колективних вірувань. Зроблено висновок, що трактування сутності динамічних зв'язків поколінь, поглиблені уявлення про перебіг поколінних генетичних процесів, визначені фактори пояснення духовно-символічної єдності поколінь можна розглядати як теоретичне підгрунтя пізнання феномену поколінності науковцями романтично-гуманітар-ного підходу.

Ключові слова: покоління, романтично-гуманітарний підхід, В. Дільтей, Х. Ортега-і-Гассет, історична ситуація, психологічна єдність, духовно-символічні поколінні основи.

Постановка проблеми. У XIX - XX століттях ідея визначення сутності духовно-символічної поколінної єдності означила романтичногуманітарні напрями дослідження питання про особливості становлення як окремої людини, так i вікових груп, формування спільного історичного поколінного досвіду в стратегічному соціальному розвитку 
суспільства. 3 одного боку, в зазначений час не існувало універсальної, цілісної теорії поколінь, але психологічні, філософські, історичні, антропологічні різноспрямовані пошуки, не поєднані, а, радше, розрізені, створювали платформу, на якій поступово, відповідно до історичної ситуації оформлювались ідеї системності психологічного, духовного і культурного поколінного життя, окреслювалися принципи формування поколінних уявлень, цінностей, норм. 3 другого боку, потужним проривом у вирішенні питань впливовості людини, групи, спільності, спільноти на соціальні процеси, способів моделювання історичного розвитку ставало поєднання різногалузевих наукових напрацювань у трактуванні явищ минулого як феноменів культурної спадщини індивідуальної творчості і суспільної психологічної єдності, пов'язування духовних основ 3 національно-етнічною сутністю із соціокультурними відносинами поколінь.

Аналіз останніх досліджень і публікацій. Розроблення теоретичних та практичних аспектів концепцій поколінь знайшло відображення в напрацюваннях учених XIX - XX століть. 3-поміж наукових публікацій, у яких аналізувалися погляди представників романтично-гуманітарного підходу, слід відмітити праці К. Вайл, Я. А. А. ван Дурна, П. Л. Ентралго, К. Мангейма, Х. Маріаса, А. Б. Фільдс, Б. Фітце та ін. Але, незважаючи на чималу кількість опублікованих наукових робіт, усе ще явно бракує досліджень, у яких би концепції міжпоколінної соціокультурної взаємодії аналізувалися комплексно як взаємопов'язані і взаємодоповнювальні теоретичні конструкції вибудовування поколінного простору. Це зумовлює необхідність подальших досліджень 3 проблематики психології соціокультурної взаємодії поколінь.

Невирімені частини загальної проблеми. Для трактування теоретичних позицій відповідно до особливостей вибудовування духовносимволічної поколінної єдності і розуміння ідеї пов'язаності історичних подій 3 конструюванням поколінної реальності слід було передусім визначити романтично-гуманітарні теоретичні основи понятійних структур, виокремити фокуси поколінного мислення, визначитися 3 інструментарієм, актуальним на етапі формування поколінної теорії в контексті романтично-гуманітарного підходу. Таким чином, формулювання передумов наукового пізнання соціально-психологічного феномену поколінності в соціокультурній площині вимагало висвітлення евристичного наскрізного ходу пошуку атрибутивних ознак поколінності, одними 3 яких стали характеристики сутності духовно-символічної єдності.

Meта cmammi: аналіз теоретичного підгрунтя пізнання феномену поколінності в працях Вільгельма Дільтея і Хосе Ортеги-і-Гассета, а відтак конкретизація розуміння сутності духовно-символічної поколінної єдності науковцями романтично-гуманітарного підходу. 
Виклад основного матеріалу дослідження. Вивчення особливостей функціонування поколінного суб'єкта в психологічних, соціальноісторичних, культурних ракурсах має тривалу історію, в якій окремі аспекти вирішення питань соціокультурної взаємодії були розглянуті в дослідженнях науковців різних галузей. Зауважимо, що кожен історичний період вирізняється специфічними акцентами у вивченні поколінь. Так, у XIX - XX століттях основні дослідження щодо поколінного аналізу проводилися в межах позитивістсько-натуралістичного, романтичногуманітарного, культурно-історичного, структурно-функціонального напрямів, які й утворили теоретико-методологічні передумови наукового пізнання феномену поколінності. Дослідження “покоління" стали засобом визначення соціально-психологічної мінливості людей у просторі історії, загальних суспільних умов існування і формотворення свідомості, у яких схожий “дух”, що формує поколінну єдність, для представників романтично-гуманітарного напрямку поколінних досліджень ставав доказом неправомірності думки щодо лінійного історичного розвитку і задавав напрям вивчення площини існування внутрішнього поколінного часу, складного для кількісного вимірювання, але доступного для якісного аналізу. Засоби формулювання думок, що змінювалися залежно від домінуючих політичних тенденцій, у працях Дільтея були розкриті в характерному для Німеччини початку XX ст. романтичному контексті і стали основою для подальшого розвитку суспільних наук. Дільтей дослідив проблему поколінь крізь призму темпоральних показників еволюції свідомості як внутрішньої історії розвитку людства. Для дослідника поняття “покоління” стало тотожним розділовим категоріям історії - годинам, місяцям, рокам, десятиліттям категоріям внутрішнього вимірювання розуміння людства (див. [10]).

Продовжуючи дослідження Ф. Ментре, Л. фон Ранке, О. Лоренца в ракурсі аналізу людського життя, систематизації його континууму, Дільтей порушив питання проявів історичності на індивідуальному (людських феноменів мови, релігії, законотворення) і соціальному (загальнопоколінної свідомості) рівнях. Він спробував за допомогою нового, авторського герменевтичного методу, де ключовим поняттям $\epsilon$ “вираження", дати трактування реальності індивідів, груп, поколінь, суспільств на основі аналізу внутрішніх станів у контексті зовнішніх умов і явищ. У царині історичного знання дослідник спирався на ідею герменевтичного кола для осягнення значення взаємозв'язків і взаємовпливів, “умовно” не пов'язаних суспільних подій, у поліфонії історичних ситуацій [9], що в майбутньому стало елементом методу поколінь Хосе Ортеги-і-Гассета [2, с. 251-295]. Аналізуючи співвідношення понять “віку” й “епохи”, Ортега пов'язав індивідуальні контексти із структурним цілим історичного світу і хронологією подій. Адже взаємозв'язок життя покоління, набуття життєвого досвіду, ментальних 
особливостей, на думку Дільтея, утримував індивідуума в певному ціннісному колі, де можливі міжпоколінні опозиції виникають саме на грунті різного віку і різних епох становлення та життєдіяльності. А зв'язок, що існує між формою суспільного поколінного життя і життєвим досвідом міжпоколінних відносин, підводив людину до можливості усвідомлення смислу життя і значення світу [3].

Для визначення поколінних показників Дільтей дослідив природний шлях міжпоколінного поділу - основи внутрішніх імпульсів, закладених природою людського існування. Він виокремив дві групи умов-факторів, що впливають на інтелектуальну культуру покоління: умови історичного часу, коли покоління перебуває на стадії активного формування, оволодіння духовною спадщиною, усвідомлення інформації-досвіду минулого; та умови нескінченної різноманітності середовища - державних і соціальних відносин та обмеження нащадків попередніми поколіннями щодо можливості подальшого прогресу.

Аналізуючи джерела гомогенності інтелектуальних літературних традицій, Дільтей фокусував увагу на виокремленні десятиліть, протягом яких здійснювалося формування свідомості представників певного часу. Він групував у хронологічному порядку видатні постаті епохи романтизму, народжені в XVI ст., які значною мірою вплинули на культуру і духовну історію Німеччини (Август Вільгельм Шлегель, Фрідріх Гегель, Фрідріх фон Шлегель, Вільгельм Ваккенродер та ін.). Дослідник здійснив аналіз гетерогенності умов їхнього становлення, об'єднавши в покоління групи народжених на початку (Готгольд Лессінг та ін.), у середині (Йоганн Вольфганг фон Гете та ін.) та другій половині століття (Фрідріх фон Гьонц, Фрідріх Гегель та ін.). При цьому, пояснюючи виникнення нових поколінь, Дільтей використав метафору хвилі.

У виокремленні курсу духовних рухів поколінь, яке, на думку Дільтея, триває години, місяці, роки і відповідає поколінному хронологічному виміру психічного часу віку й людського життя в цілому, дослідник намагався сформулювати зміст поняття покоління: це (1) поняття тимчасового простору, яким вимірюється людське життя (час від народження до вікової межі близько 30-ти років); (2) це індивідисучасники, дитинство, юність яких проходили в один час, які мали єдиний історичний досвід, були пов'язані тісними соціальними відносинами і в роки становлення зазнавали єдиних соціальних впливів [1].

Як пише Хуліан Маріас, щодо першої позиції Дільтей залишався вірним генеалогічній інтерпретації поняття покоління, хоч означені ним тридцятирічні інтервали домінування покоління не завжди відповідали проаналізованим поколінним групам, а саме: біологічне покоління, на його думку, не відповідало соціально-історичному. Дослідник пояснював це тим, що тривалість поколінного життя має відмінності і не вкладається в зазначені тридцятирічні межі. Друга позиція, яка 
розкривала особливості формування спільних ідей покоління, охоплювала значущі чинники людського та історичного життя, що в період юнацтва і молодості створюють ідею покоління, яка зберігається, оформлюється і вже не витісняється наступними життєвими враженнями. Таку дієвість ідеї поколінь Дільтей представляв у ключі міжособового спілкування малої групи осіб і не переносив поняття в ракурс поколінної структурності суспільства. За його трактуванням, окремі особистості генеалогічних поколінь не відповідали історичному поколінню, адже не переживали спільні значущі глобальні історичні події, не були складниками структури суспільства, продуктом колективної, групової життєдіяльності, а лише окремим людським життям письменників, поетів, філософів, художників, прикладами життєтворчості груп, об'єднаних спільною діяльністю [11]. Тому, вже як історико-соціальна одиниия, покоління ставало доступним для піз-нання завдяки аналізу зв'язків історичних явищ, у яких людина, представник покоління, утілює себе.

Позиція використання поняття покоління як інструменту систематизації й аналізу безлічі фактів і даних також була близька Ортезі. Цей фокус значення соціально-історичних подій, їхнього впливу на індивідуальне/групове і залежності від нього було реалізовано за допомогою новоутвореної методології розширення пізнання поколінних реалій буття, розуміння слідів життєдіяльності. У сформульованому ним методі поколінь представлені конструкти, які на підвалинах ідей мислителів (минулого і того, сучасного) були оформлені в самостійну теорію.

Для розуміння основ методу поколінь Ортеги слід означити постулати життєвої філософії, закладені Дільтеєм. Вони відтак дістали наскрізний розвиток у доробку Ортеги. Адже антропологізм й історизм Ортеги викристалізувалися з антропофілософських уявлень та інтерпретаційних конструкцій понять часу, історії, життя, духу епохи, життєдіяльності тощо Дільтея. Так, життєву реальність, згідно 3 аналізом Дільтея представлену в ракурсі людської історико-соціальної зовнішньої реальності, де поколінний історизм задає параметри колективної, групової єдності в безперервному процесі підлаштування (до вимог пращурів), адаптування (до умов сучасного) і реконструкції (“своєї” епохи як унікальної і неповторної, яка не "передує наступній”, a є єдино “оптимальною...") [5], у роботах Ортеги було розглянуто 3 позиції внутрішньої реальності. На думку філософа, "реальність життя не в тому, чим вона здається спостерігачеві ззовні. Навпаки, вона відкрита лише для того, хто бачить іiі зсередини" [2]. Тому первинним зав-данням дослідника $є$ не оцінка реальності поколінного життя за принципами стороннього спостерігача, а оцінка (зсередини!) світу, сконструйованого людиною, представником покоління. Адже в основі історичної побудови суспільства завжди буде людина, що створює світи, в яких живе. Але поступово змінюються світи, змінюється життя, i 
ці зміни впливають на людину. До речі, Ортега вважав, що душа і тіло людини є психофізіологічним суб' єктом, який у процесі трансформацій світотворення може не змінюватись, а людина, як представник покоління, саме $і$ є життям. I якщо "реальність життя... відкрита лише тому, хто бачить іiі зсередини” [2, с. 252], то пізнання людини i, відповідно, покоління можливе лише шляхом пізнання іï/його незмінної духовної сутті.

Зовнішня реальність, за Дільтеєм, навпаки, поширювалася на духовну життєвість, пояснювала причинність індивідуального і життєвих відчуттів. Але вибудовування духовного світу й історичного знання відбивало залежність від особливостей історичного процесу, який впливає на розвиток духовного світу поколінь, від якого й залежать фоми побудови духовного світу. Ці зв'язки і взаємовпливовість елементів духовної субстанції, що є поясненням суті духовної структурності, опосередковували для Дільтея розвиток знань історії світу [5].

Але якщо зміст, розуміння історії ставали можливими завдяки вивченню структур і форм людського життя, а людина - це життя, яке "безперервно змінюе структуру" [2, с. 256], якщо зміни історичного світу (світу людини) не руйнують, не перебудовують докорінно конструкцію його основних елементів і загальна будова залишається "умовно" незмінною, - людині (поколінню людини) здається, що змінюється лише дещо навкруги, а не сам світ переплетених життів, колективних вірувань, які Ортега ототожнював з поняттями “ідей епохи”, “духу часу”. Така внутрішня реальність (значуща лише для окремого індивіда), пронизана, просякнута ідеями часу, суспільними переконаннями, уже не була відокремленою індивідуальною реальністю, адже особисті вірування, їх сукупність ставали відлунням і продуктом колективних вірувань. Колективне для Ортеги створювалося і ставало особистим в загальнообов'язковому поколінному світі. Внутрішня реальність ставала зовнішньою. Вірування, створені часом, відкривали особливості незмінного “духу часу”, духовного світу поколінь.

I знову, повертаючись до питання розуміння особливостей пізнання самих себе та інших, у наукових напрацюваннях Дільтея простежуємо пов'язаність життя особистого й іншого (групового, суспільного) в процесі набування досвіду, аналізу поведінки, вираження і розуміння [4]. Так, за Дільтеєм, життям $є$ не тільки окрема людина, це те, що вже пережито, зрозуміло, стало досвідом [8]. Індивідуальні життєві досвіди розширюються до загальних цінностей, правил, цілей, стають витвором спільного життя, нормами життя окремих людей, об'єднаних у спільноти, в яких формуються звичаї, традиції, в історичному процесі оформлюється духовний світ епохи [6]. Таким чином, життя - це не тільки (1) сукупний досвід окремої людини, (2) це індивідуальні стани в індивідуальних формах життєвих реалій, (3) це знання про реальність, 
які мають вікові і соціальні передумови, що й опосередковує міжпоколінну взаємодію в часі [7]. Отже, для Дільтея життя - це обмежений час, за який людина проходить різні вікові фази. Для Ортеги життя це людина, занурена в хронологічний вік, процес співіснування людей, які перебувають на різних (своїх хронологічних) життєвих вікових відрізках (котрі не мають для всіх людей універсальної довжини) - або дитинства, або юності, або дорослості, або старості [там само, с. 259]. Людське життя - це багатомірна, синтетична реальність не окремої людини, а "реальність реальностей” [там само, с. 250] поколінь, у якій життя кожного є життям покоління, а життя покоління є особистим життям. Покоління йдуть одне за одним, співіснують, перебувають одночасно в міжпоколінному і внут-рішньопоколінному просторах, але саме незмінні душа і тіло в мінливому житті стають, за Ортегою, причиною і ритмом історичних змін: реальність охоплює одночасно три вікові поколінні пласти (покоління Прабатьків, Батьків, Дітей), які співіснують, $\epsilon$ нерозривно пов'язаними “i, через споконвічні відмінності, непримиренно ворожими одне до одного" [там само, с. 260]. Ворожі саме зіткненням незмінних субстанцій з різними віковими параметрами, які існують за принципами “свого" періоду молодості, але перебувають на єдиній арені часу. Отже, Ортега, метод якого грунтується на основі постійно змінюваних умов життя в кругообігу впливів різновікових спільнот, розглядає покоління як ціліс-ний життєвий зразок, як спільність однолітків, що співіснують в одному колі, об'єднаних спільними ознаками - єдністю віку (близькі в історичній хронології дати народження), наявністю життєвих контактів, спільним місцем в історичному часі та життєвому просторі. "Покоління... подібне до нового соціального тіла, 3 його окремішньою меншиною і його натовпом... Покоління, як динамічний компроміс між ма-сою та індивідуальністю, $\epsilon$ найважливішим поняттям в історії..” [12]. Ортега співвідносить поняття віку представників поколінь із життєвою реальністю, яка змінюється внаслідок переходу до наступного вікового періоду, що оформлює оновлений “образ” життя. Для Ортеги вікові періоди мають суб'єктивну, “умовну” тривалість, адже саму ідею вікового розподілу він вважав суб'єктивною: незмінна субстанція духу і тіла має лише різні стани, відмінні на різних етапах життя (!). Він відмовлявся зводити трактування людини лише до біологічного організму, а акцентував увагу на континуумі життя: це - драма, це - доля, а вік - лише мінливий стан, тип життєвого конструювання, самостійного життевого творення, оновлення світу і перетворення його на світ, значущий для покоління на історичному етапі. Це етап вирішення завдань, необхідних для осягнення світу, а далі - підтримування і збереження створеного світу. Але серед етапів вибудовування поколінної реальності часовий відрізок від 30 до 45 років Ортега виокремлював як час 
закладання оригінальної реальності, початку творчості і полеміки, а далі (від 45 до 60 років) - панування і правління [2, с. 273]. Цей 15-річний період домінування покоління, за Ортегою, проходив у середовищі одночасної реалізації особистих завдань інших поколінь, співіснування різновікових сучасників. Адже вік - це не тільки стан духу і тіла, тип світотворення, етап життя, це - "зона дат", які окреслюють покоління. У методі покоління Ортега визначив постулати, що не суперечать життєвим фактам історичності. По-перше, "час", а точніше "дух часу", спільний для покоління певної епохи. По-друге, історичність поколінного існування, яка була фугою одночасного сьогодення поколінь (у часовому вимірі сьогодення різних поколінь відрізняється за світосприйманням, але є сьогоденням їхньої поколінної реальності). Потретє, сьогодення поколінь не існує відокремлено, а реалізується в реальності, що $є$ похідною від минулого; тому минуле, за Ортегою, було завжди актуальним для нащадків, адже нащадки “зберігають" у собі “дух часу” пращурів. По-четверте, інтервал часу домінування, відведений історією, є незмінним і дорівнює 15 рокам. По-п’яте, покоління (Дітей, Батьків, Прабатьків) живуть у реальних історичних зв'язках, що стає ключовим методом історичного пізнання [там само, с. 269]. I, по-шосте, поколінна пам'ять (Дітей, Батьків, Прабатьків) щодо значущих історичних подій визначає різну їх цінність і різне їх трактування. Таким чином, достовірне розуміння сьогодення поколінь стає, за методом Ортеги, неможливим без ретроспективного погляду з минулого i передбачення можливого майбутнього.

Завершуючи огляд методу, спробуймо на основі змінних і незмінних елементів світотворення поколінь виокремити теоретичний ланцюжок основних позицій, що підводить до головного питання теорії поколінь Ортеги: як змінюється структура життя, що опосередковує стани душі і тіла на різних вікових етапах не окремої людини, а окремого покоління? Отже, у методі Ортеги:

- душа і тіло людини є психофізіологічним суб'єктом, який у процесі трансформування світотворення не змінюється, а має різні стани, що різняться на вікових етапах життя (тривалістю 15 років).

- Людина - це Життя, яке постійно змінює структуру.

У процесі життя людина постійно, задля самоствердження, творить і реконструює Світ як засіб існування, унаслідок чого Світ постійно змінює свою структуру. Світові трансформації змінюють людину (іiі реальність, реальність ії покоління). Коло замикається, що дає змогу вивести формули теорії поколінь Ортеги: (1) “Людина - це життя, життя - це світ, світ - це людина!”. I (2): якщо окрема людина - частина "духовного світу" поколінь, який відбиває реальність окремих людських реальностей, тоді “покоління - це життя, життя - це світ, світ - це покоління!"”. 
Так, створюючи історію поколінь, Ортега вибудував метафізичні і соціологічні конструкиії, що стали продуктом інтеграції філософської, антропологічної, історичної думки і водночас надактуальною необхідністю з погляду створення засобів розуміння соціальної історичності європейської людини. Ортега сформулював не відірвані від буття теоретичні зв'язки, не інформаційні моделі, а інструменти читання поколінних реальностей, необхідні в ситуаціях, коли свідомість історичності та історична інтерпретація $є$ домінантними, а сконструйована сувора теорія поколінь стає можливим методом історичного пізнання.

Таким чином, незважаючи на гетерогенність поколінних ідей, В. Дільтей і Х. Ортега-і-Гассет створили теоретичне підгрунтя для пізнання феномену поколінності, конкретизували розуміння сутності динамічних зв 'язків поколінь як суб'єктів історичної творчості і спільного спрямування поколінного руху, поглибили уявлення про перебіг поколінних генетичних процесів, визначили фактори пояснення духовно-символічної єдності поколінної спільноти як необхідні передумови формулювання системної теорії поколінь.

Висновки. Отже, на основі узагальнення ідей В. Дільтея i $\mathrm{X}$. Ортеги-і-Гассета - найвідоміших представників романтично-гуманітарного підходу в пізнанні феномену поколінності - визначено, що поняття покоління може трактуватися з генеалогічних (Дільтей) і філософсько-історичних (Ортега) позицій. Обидва науковці розглядали покоління як групу осіб, що виокремлюється за спільними ознаками: “зоною” дат народження, у роки становлення набутим історичним досвідом, соціальними відносинами - та об'єднується в соціальні страти відповідно до загальних культурних тенденцій, національних та етнічних форм, мовних особливостей, територіального розташування. Також 3'ясовано, що роки функціонування поколінь у часовому еквіваленті обмежуються певним терміном (Дільтей), при цьому періодом домінування покоління сучасників над їхніми пращурами і нащадками було визначено 15-річний відрізок часу (Ортега).

Проаналізовано представлені у творчості Дільтея та Ортеги природничі і духовні антитези як необхідні елементи дослідження поколінь, як поєднання життя і досвіду, минулого і сучасного, змінного і незмінного. Розглянуто виокремлені науковцями романтично-гуманітарного підходу показники поколінної єдності як константи духовної сутності, іiі ознаки, функціональність, автентичність тощо. Зауважено, що в теоретичних позиціях Дільтея соціальні еволюційні курси духовних рухів були пов'язані з поколінним хронологічним виміром психічного часу, формою суспільного життя і набутим досвідом. Проаналізовано заявлену в теоретичних постулатах залежність особливостей еволюційного історичного шляху конструювання духовного світу й історичного знання поколінь (Дільтей), незмінність субстанції духовної суті - 
“душі і тіла” як психофізіологічного суб'єкта - i ритму історичних змін у світі переплетених життів, колективних вірувань (Ортега). Як теоретичне підгрунтя пізнання феномену поколінності з позицій науковців романтично-гуманітарного підходу визначено трактування сутності динамічних зв'язків поколінь; поглиблені уявлення про перебіг поколінних генетичних процесів; фактори пояснення духовно-символічної єдності поколінь.

Результати проведеного дослідження дають змогу здійснити синхронізацію наукових трактувань поняття “покоління" і визначити теоретико-методологічні передумови пізнання цього феномену.

\section{Лimepamypa}

1. Дильтей B. Собрание сочинений : в 6 т. Т. $1:$ Введение в науки о духе / Вильгельм Дильтей. - Москва, 2000. - 762 с.

2. Ортега-и-Гассет Х. Избранные труды / Хосе Ортега-и-Гассет. - Москва : Весь Мир, 1997. - 704 с.

3. Dilthey W. Der Aufbau der geschichtlichen Welt in den Geisteswissenschaften [Electronic resourse] / Wilhelm Dilthey. - Berlin, 1910. - Accee mode : http://www.zeno.org/nid/20009162259 (Last accessed: 6.10.2017).

4. Dilthey W. Der Aufbau der geschichtlichen Welt in den Geisteswissenschaften. I. Abgrenzung der Geisteswissenschaften [Electronic resourse] / Wilhelm Dilthey. Accee mode : http://www.zeno.org/Philosophie/M/Dilthey,+Wilhelm/Der+ Aufbau+der+geschichtlichen+Welt+in+den+Geisteswissenschaften/II.+Die+Ve rschiedenheit+des+Aufbaus+in+den+Naturwissenschaften+und+den+Geisteswi ssenschaften (Last accessed: 13.10.2017).

5. Dilthey W. Der Aufbau der geschichtlichen Welt in den Geisteswissenschaften. II. Die Verschiedenheit des Aufbaus in den Naturwissenschaften und den Geisteswissenschaften [Electronic resourse] / Wilhelm Dilthey. - Accee mode : http://www.zeno.org/Philosophie/M/Dilthey,+Wilhelm/Der+Aufbau+der+gesc hichtlichen+Welt+in+den+Geisteswissenschaften/II.+Die+Verschiedenheit+des +Aufbaus+in+den+Naturwissenschaften+und+den+Geisteswissenschaften (Last accessed: 12.10.2017).

6. Dilthey W. Der Aufbau der geschichtlichen Welt in den Geisteswissenschaften. III. Allgemeine Sätze über den Zusammenhang der Geisteswissenschaften. 2. Die Lebenserfahrung [Electronic resourse] / Wilhelm Dilthey. - Accee mode : http://www.zeno.org/Philosophie/M/Dilthey,+Wilhelm/Der+Aufbau+der+gesc hichtlichen+Welt+in+den+Geisteswissenschaften/III.+Allgemeine+S\%C3\% A4tze+\%C3\%BCber+den+Zusammenhang+der+Geisteswissenschaften/2.+Die + Struktur+der+Geisteswissenschaften/1.+Das+Leben+und+die+Geisteswissens chaften/2.+Die+Lebenserfahrung (Last accessed: 13.10.2017).

7. Dilthey $W$. Der Aufbau der geschichtlichen Welt in den Geisteswissenschaften. III. Allgemeine Sätze über den Zusammenhang der Geisteswissenschaften. 3. Unterschiede der Verhaltungsweisen im Leben und Klassen der Aussage in der Lebenserfahrung [Electronic resourse] / Wilhelm Dilthey. - Accee mode : http://www.zeno.org/Philosophie/M/Dilthey,+ Wilhelm/Der+Aufbau+der+geschichtlichen+Welt+in+den+Geisteswissenschaft 
en/III.+Allgemeine+S\%C3\%A4tze+\%C3\%BCber+den+Zusammenhang+der+ Geisteswissenschaften/2.+Die+Struktur+der+Geisteswissenschaften/1.+Das+L eben+und+die+Geisteswissenschaften/3.+Unterschiede+der+Verhaltungsweise $\underline{\text { n+im+Leben+und+Klassen+der+Aussage+in+der+Lebenserfahrung }}$

(Last accessed: 13.10.2017).

8. Dilthey $W$. Der Aufbau der geschichtlichen Welt in den Geisteswissenschaften. 1. Das Leben und die Geisteswissenschaften. 1. Das Leben [Electronic resourse] / Wilhelm Dilthey. - Accee mode : http://www.zeno.org/Philosophie/M/Dilthey, +Wilhelm/Der+Aufbau+der+geschichtlichen+Welt+in+den+Geisteswissenscha ften/III.+Allgemeine+S\%C3\%A4tze+\%C3\%BCber+den+Zusammenhang+der + Geisteswissenschaften/2.+Die+Struktur+der+Geisteswissenschaften/1.+Das+ Leben+und+die+Geisteswissenschaften/1.+Das+Leben (Last accessed: 13.10.2017).

9. Foucaults M. Konzept der Genealogie im Hinblick auf die folgende Frage: Wie kann historische Erkenntnis überhaupt möglich sein? [Electronic resourse] / Michel Foucaults // Erasmus-Mundus Europhilosophie. - Access mode: https://is.cuni.cz/webapps/zzp/download/120144433 (Last accessed: 3.10.2017).

10. Mannheim K. El problema de las generaciones [Electronic resourse] / Karl Mannheim // Monografico sobre Karl Mannheim. - Access mode : http://www.reis.cis.es/REIS/PDF/REIS 062 12.pdf (Last accessed: 15.11.2017).

11. Marías $J$. El método histórico de las generaciones. Instituto de humanidades. Revistas des Occidentes Bárbara de Biaganza / Julian Marias. - Madrid, 1949. $192 \mathrm{p}$.

12. Ortega y Gasset J. La idea de las generaciones. Antologia del Ensauo [Electronic resourse] / Jose Ortega y Gasset. - Access mode : https://www.ensayistas.org/antologia/XXE/ortega/ortega3.htm (Last accessed: 14.10.2017).

\section{References}

1. Dilthey, W. (2000). Sobraniye sochineniy. Vvedeniye v nauki o dukhe: $v 6 t$. T. 1 [Collected Works: Introduction to the science of the spirit: in 6 volumes. Vol. 1]. Moscow (rus).

2. Ortega-i-Gasset, H. (1997). Izbrannyye trudy [Selected Works]. Moscow: Ves Mir Publ. (rus).

3. Dilthey, W. (1910). Der Aufbau der geschichtlichen Welt in den Geisteswissenschaften. Berlin, http://www.zeno.org/nid/20009162259 (Last accessed: 6.10.2017) (germ).

4. Dilthey, W. (2017). Der Aufbau der geschichtlichen Welt in den Geisteswissenschaften. I. Abgrenzung der Geisteswissenschaften, http://www.zeno.org/Philosophie/M/Dilthey,+Wilhelm/Der+Aufbau+der+gesc hichtlichen+Welt+in+den+Geisteswissenschaften/II.+Die+Verschiedenheit+des + Aufbaus+in+den+Naturwissenschaften+und+den+Geisteswissenschaften (Last accessed: 13.10.2017) (germ).

5. Dilthey, W. (2017). Der Aufbau der geschichtlichen Welt in den Geisteswissenschaften II. Die Verschiedenheit des Aufbaus in den Naturwissenschaften und den Geisteswissenschaften, http://www.zeno.org/ Philosophie/M/Dilthey,+Wilhelm/Der+Aufbau+der+geschichtlichen+Welt+in+ 
$\underline{\text { den+Geisteswissenschaften/II.+Die+Verschiedenheit+des }+ \text { Aufbaus }+ \text { in }+ \text { den }+\mathrm{N}}$ aturwissenschaften+und+den+Geisteswissenschaften (Last accessed: 12.10.2017) (germ).

6. Dilthey, W. (2017). Der Aufbau der geschichtlichen Welt in den Geisteswissenschaften. III. Allgemeine Sätze über den Zusammenhang der Geisteswissenschaften. 2. Die Lebenserfahrung, http://www.zeno.org/ Philosophie/M/Dilthey,+Wilhelm/Der+Aufbau+der+geschichtlichen+Welt+in+ den+Geisteswissenschaften/III.+Allgemeine+S\%C3\%A4tze+\%C3\%BCber+de $\underline{\mathrm{n}+\text { Zusammehang+der+Geisteswisseschaften/2.+Die+Struktur+der+Geisteswiss }}$ enschaften/1.+Das+Leben+und+die+Geisteswissenschaften/2.+Die+Lebenserfah rung (Last accessed: 13.10.2017) (germ).

7. Dilthey, W. (2017). Der Aufbau der geschichtlichen Welt in den Geisteswissenschaften. III. Allgemeine Sätze über den Zusammenhang der Geisteswissenschaften. 3. Unterschiede der Verhaltungsweisen im Leben und Klassen der Aussage in der Lebenserfahrung, http://www.zeno.org/ Philosophie/M/Dilthey,+Wilhelm/Der+Aufbau+der+geschichtlichen+Welt+in+ den+Geisteswissenschaften/III.+Allgemeine+S\%C3\%A4tze+\%C3\%BCber+de n+Zusammenhang+der+Geisteswissenschaften/2.+Die+Struktur+der+Geistesw issenschaften/1.+Das+Leben+und+die+Geisteswissenschaften/3.+Unterschiede + der+Verhaltungsweisen+im+Leben+und+Klassen+der+Aussage+in+der+Lebense rfahrung (Last accessed: 13.10.2017) (germ).

8. Dilthey, W. (2017). Der Aufbau der geschichtlichen Welt in den Geisteswissenschaften. 1. Das Leben und die Geisteswissenschaften. 1. Das Leben, http://www.zeno.org/Philosophie/M/Dilthey,+Wilhelm/Der+Aufbau+ der+geschichtlichen+Welt+in+den+Geisteswissenschaften/III.+Allgemeine+ S\%C3\%A4tze+\%C3\%BCber+den+Zusammenhang+der+Geisteswissenschafte $\underline{\mathrm{n} / 2 .+\mathrm{Die}+\text { Struktur+der+Geisteswissenschaften/1.+Das+Leben+und+die+Geiste }}$ swissenschaften/1.+Das+Leben (Last accessed: 13.10.2017) (germ).

9. Foucaults, M. (2017). Konzept der Genealogie Im Hinblick auf die folgende Frage: Wie kann historische Erkenntnis überhaupt möglich sein? Erasmus-Mundus Europhilosophie. Samira Elyasi, https://is.cuni.cz/webapps/zzp/download/ 120144433 (Last accessed: 3.10.2017) (germ).

10. Mannheim, K. (2017). El problema de las generaciones. Monografico sobre Karl Mannheim, http://www.reis.cis.es/REIS/PDF/REIS_062_12.pdf (Last accessed: 15.11.2017) (spanish).

11. Marías, J. (1949). El método histórico de las generaciones. Instituto de humanidades. Revistas des Occidentes Bárbara de Biaganza. Madrid (spanish).

12. Ortega y Gasset, J. (2017). La idea de las generaciones. Antologia del Ensauo, https://www.ensayistas.org/antologia/XXE/ortega/ortega3.htm (Last accessed: 14.10.17) (spanish).

\section{Dovhan N. O. Spiritual-and-Symbolic Unity Of Generations: Wilhelm Dilthey and Jose Ortega y Gasset}

In the context of the analysis of the peculiarities of the generational space designing by the scientists of the romantic-and-humanitarian approach, there are singled out the ideas of finding the essence of the spiritual and symbolic unity of the generations and linking historical events with the design of the generational reality. 
There is substantiated the necessity of determining the attributive characteristics of generations in the works of Wilhelm Dilthey and Jose Ortega y Gasset as the theoretical basis for the knowledge of generationality phenomenon. A comparative analysis of the differences between the genealogical and philosophical and historical positions of scientists in the interpretation of generation concept is carried out. There are revealed the common signs by which Dilthey and Ortega were uniting the generation into a group of people (the common "zone" of birth dates, historical experience in the years of formation, social relations, common cultural tendencies, national and ethnic forms, language features, territory location). Indicators of generational unity through the constants of spiritual essence, its features, functionality, authenticity, etc. are presented. The natural and spiritual generational antitheses in the combination of life and experience, past and present, changing and unchanging are analyzed. It is determined that the periods of generations functioning have a limited period by the genealogical principle, and the social evolutionary courses of spiritual movements are related to the generational chronological measurement of psychic time, to the form of social life and acquired experience (Dilthey), while the period of dominance of the contemporaries' generation over their ancestors and offsprings is limited only to a fifteen-year period (Ortega). As a result of the analysis of variables and constants of the generational phenomenon, it was found that Dilthey makes links between the peculiarities of the evolutionary historical path of constructing the spiritual world and the historical knowledge of generations, and Ortega, by contrast, emphasizes the immutable substance of the spiritual essence "soul and body" as a psycho-physiological subject and of the rhythm of historical changes in the world of intertwined lives and collective beliefs. The conclusion is made that the interpretation of the essence of the dynamic connections of generations, the deepening of the idea of the course of generational genetic processes, the factors of explanation of the spiritual and symbolic unity of generations can be considered as the theoretical basis for the knowledge of the phenomenon of generationality by the scientists of the romantic-humanitarian approach.

Key words: generation, romantic-and-humanitarian approach, W. Dilthey, J. Ortega y Gasset, historical situation, psychological unity, spiritual-and-symbolic generational foundations.

(C) Довгань Н. О. 